\title{
25 Research Square \\ Landslide Vulnerability Assessment in Devikulam Taluk, Idukki District, Kerala Using Gis and Machine Learning Algorithms
}

Bhargavi Gururajan ( $\sim$ bhargavi62@gmail.com )

SRMIST: SRM Institute of Science and Technology

Arun nehru Jawaharlal

SRMIST: SRM Institute of Science and Technology

\section{Research Article}

Keywords: Landslide, geographical hazard, Matthews correlation efficient (MCE), Linear Discriminant Analysis (LDA)

Posted Date: June 14th, 2021

DOI: https://doi.org/10.21203/rs.3.rs-487079/v1

License: (c) (i) This work is licensed under a Creative Commons Attribution 4.0 International License.

Read Full License 


\section{Abstract}

Landslide is a chronic problem that causes severe geographical hazard due to development activities and exploitation of the hilly region and it occurs due to heavy and prolongs rain flow in the mountainous area. Initially, a total of 726 locations were identified at devikulam taluk, Idukki district (India). These landslide potential points utilised to construct a spatial database. Then, the geo spatial database is then split randomly into $70 \%$ for training the models and $30 \%$ for the model validation. This work considers Seven landslide triggering factors for landslide susceptibility mapping. The susceptibility maps were verified using various evaluation metrics. The metrics are sensitivity, specificity, accuracy, precision, Recall, Matthews correlation efficient (MCE), Area Under the Curve (AUC), Kappa statistics, Mean Absolute Error (MAE), Mean Square Error (MSE).The proposed work with 5 advanced machine learning approaches assess the landslide vulnerability.It includes Logistic Regression (LR), K Nearest Neighbor (KNN), Decision tree classifier, Linear Discriminant Analysis (LDA) and Gaussian Naïve Bayes modelling and comparing their performance for the spatial forecast of landslide possibilities in the Devikulam taluk. In experimental results, Decision tree classifier performs the most reliable performance with an overall accuracy rate of $99.21 \%$.

\section{Full Text}

This preprint is available for download as a PDF.

\section{Figures}




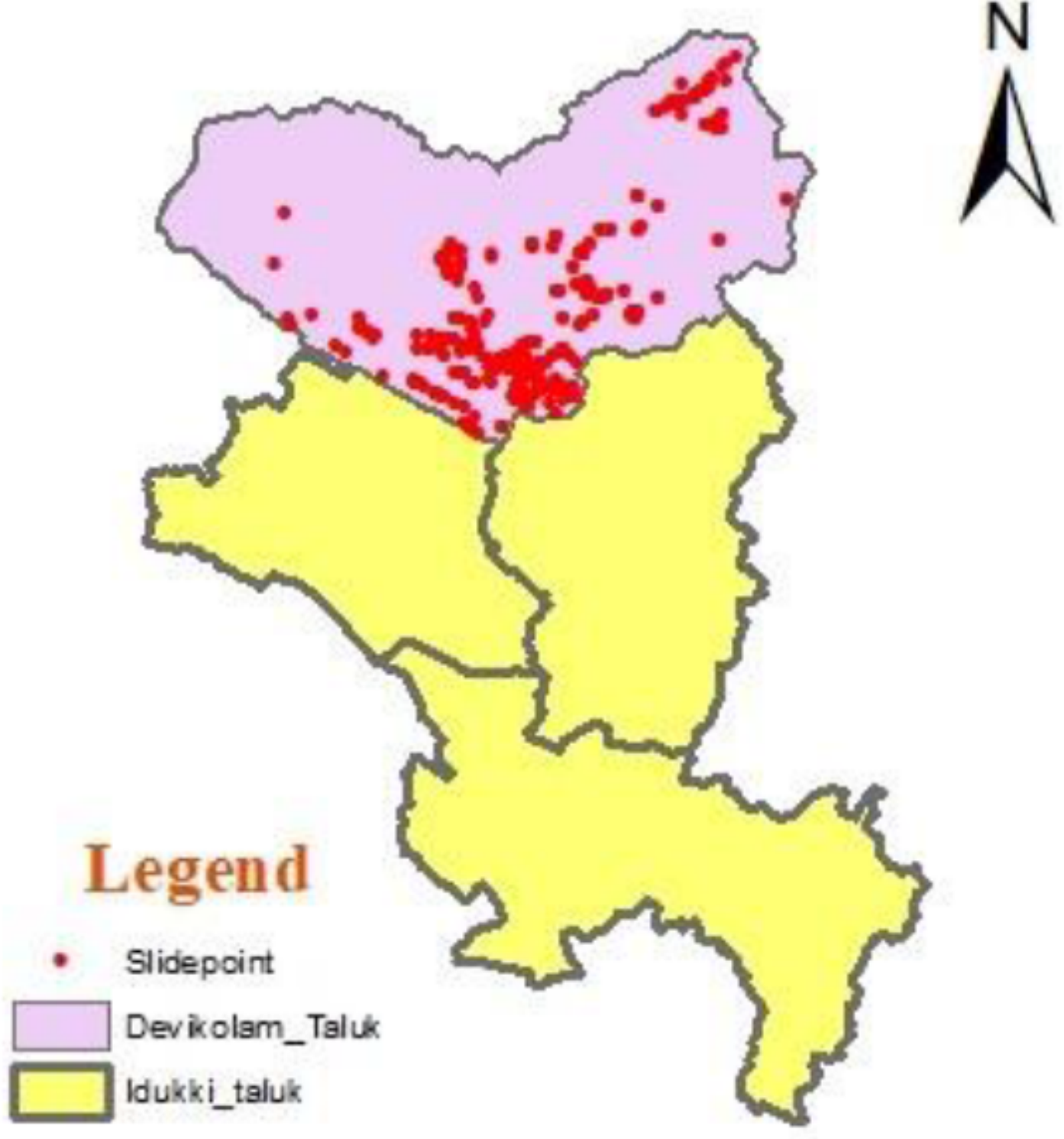

Figure 1

The Red landslide points highlights the Devikulam taluk in Idukki district. Note: The designations employed and the presentation of the material on this map do not imply the expression of any opinion whatsoever on the part of Research Square concerning the legal status of any country, territory, city or area or of its authorities, or concerning the delimitation of its frontiers or boundaries. This map has been provided by the authors. 


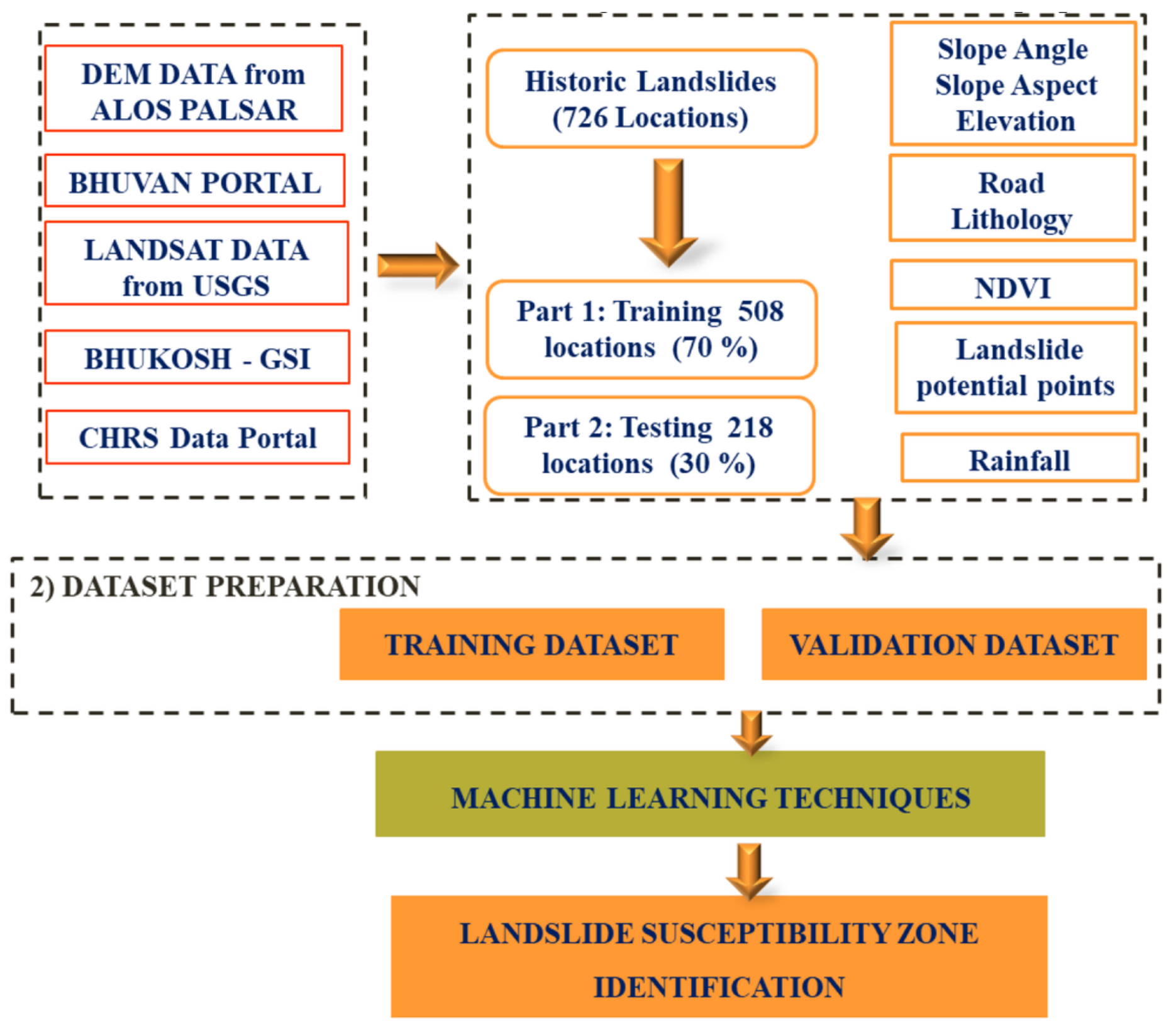

Figure 2

The proposed Methodology to identify the landslide susceptibility zone. Note: The designations employed and the presentation of the material on this map do not imply the expression of any opinion whatsoever on the part of Research Square concerning the legal status of any country, territory, city or area or of its authorities, or concerning the delimitation of its frontiers or boundaries. This map has been provided by the authors. 


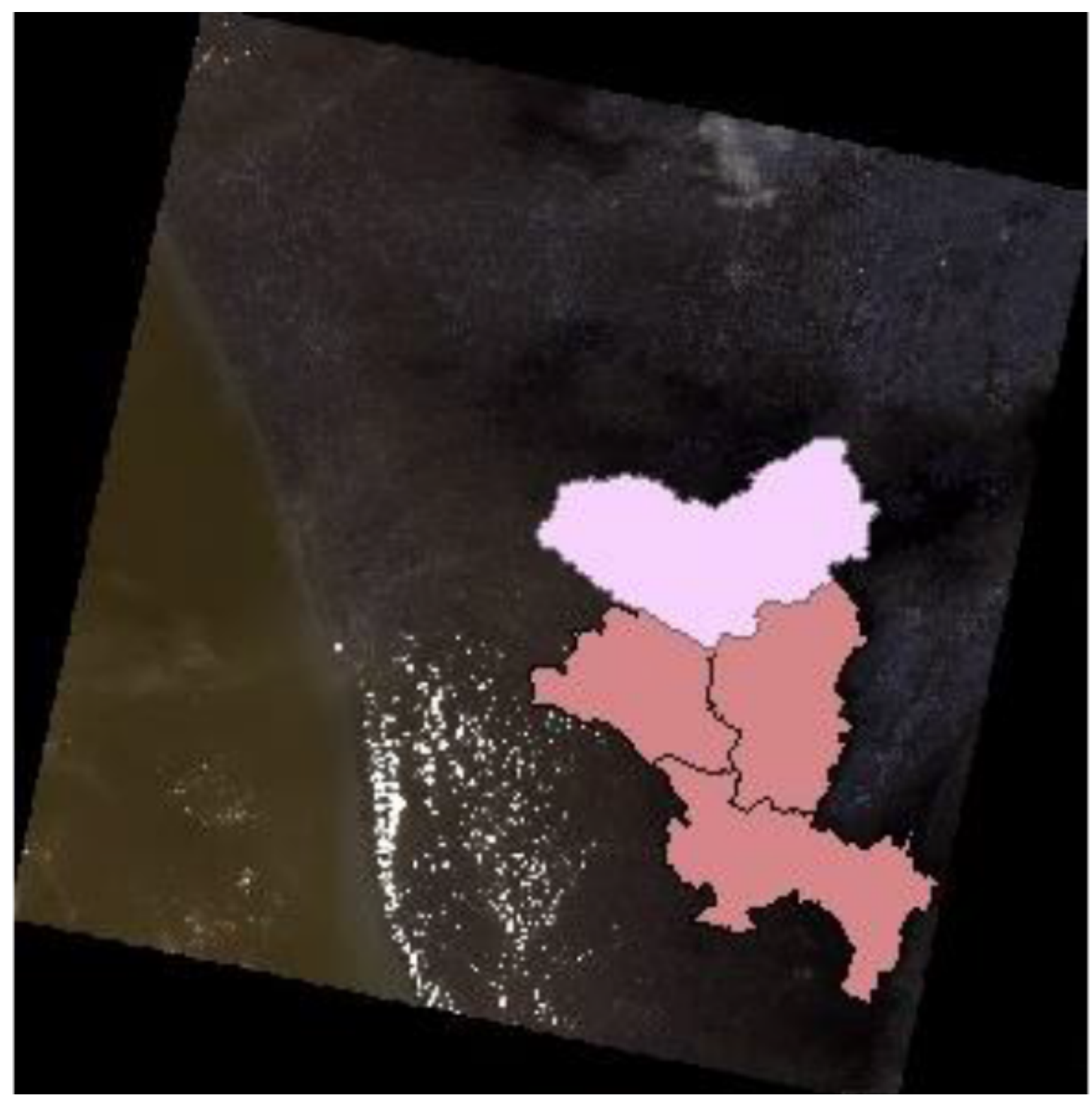

\section{Figure 3}

Landsat Satellite Tile Image of Idukki District. Note: The designations employed and the presentation of the material on this map do not imply the expression of any opinion whatsoever on the part of Research Square concerning the legal status of any country, territory, city or area or of its authorities, or concerning the delimitation of its frontiers or boundaries. This map has been provided by the authors. 


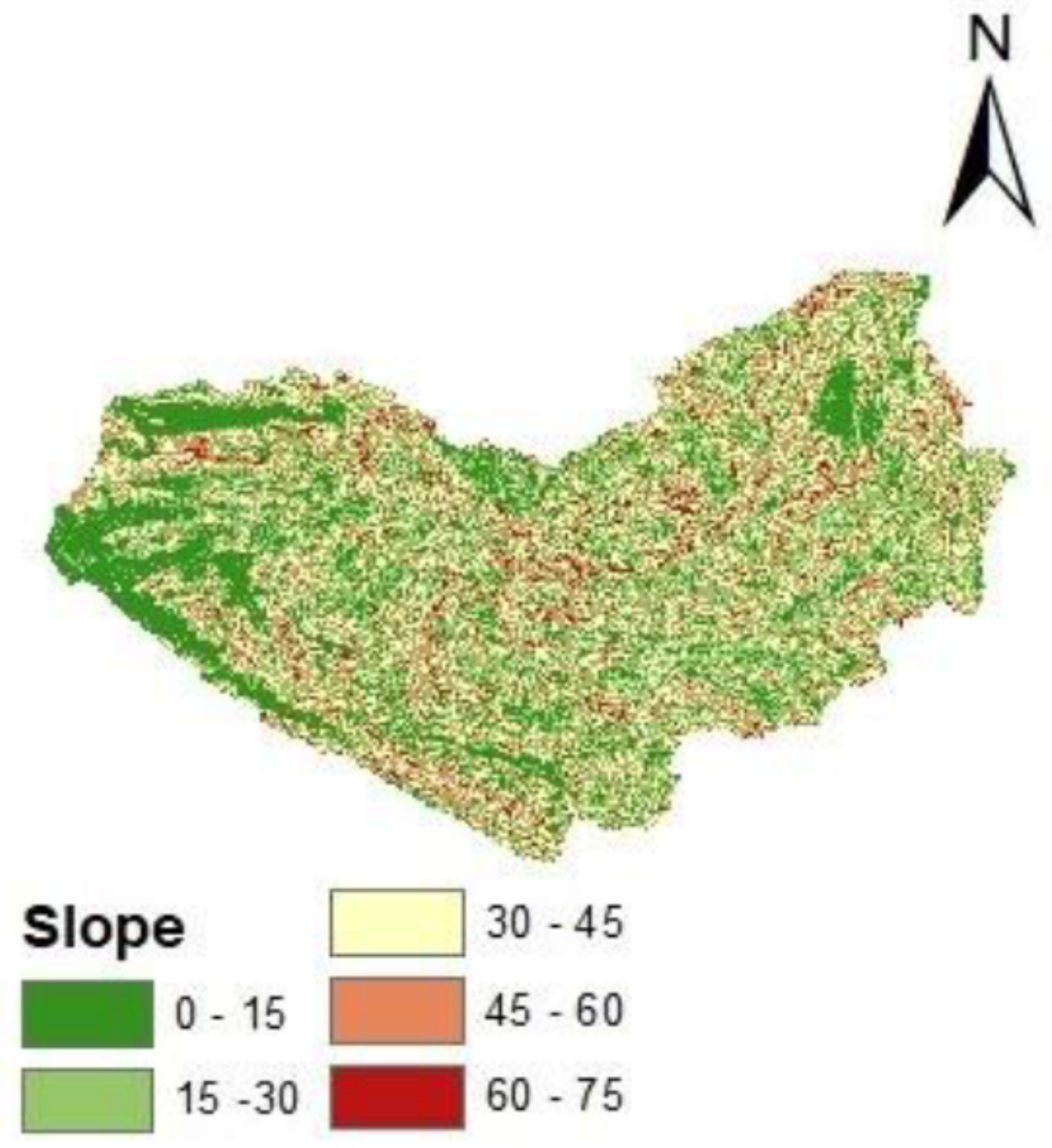

\section{Figure 4}

Slope angle map for the study area. Note: The designations employed and the presentation of the material on this map do not imply the expression of any opinion whatsoever on the part of Research Square concerning the legal status of any country, territory, city or area or of its authorities, or concerning the delimitation of its frontiers or boundaries. This map has been provided by the authors. 


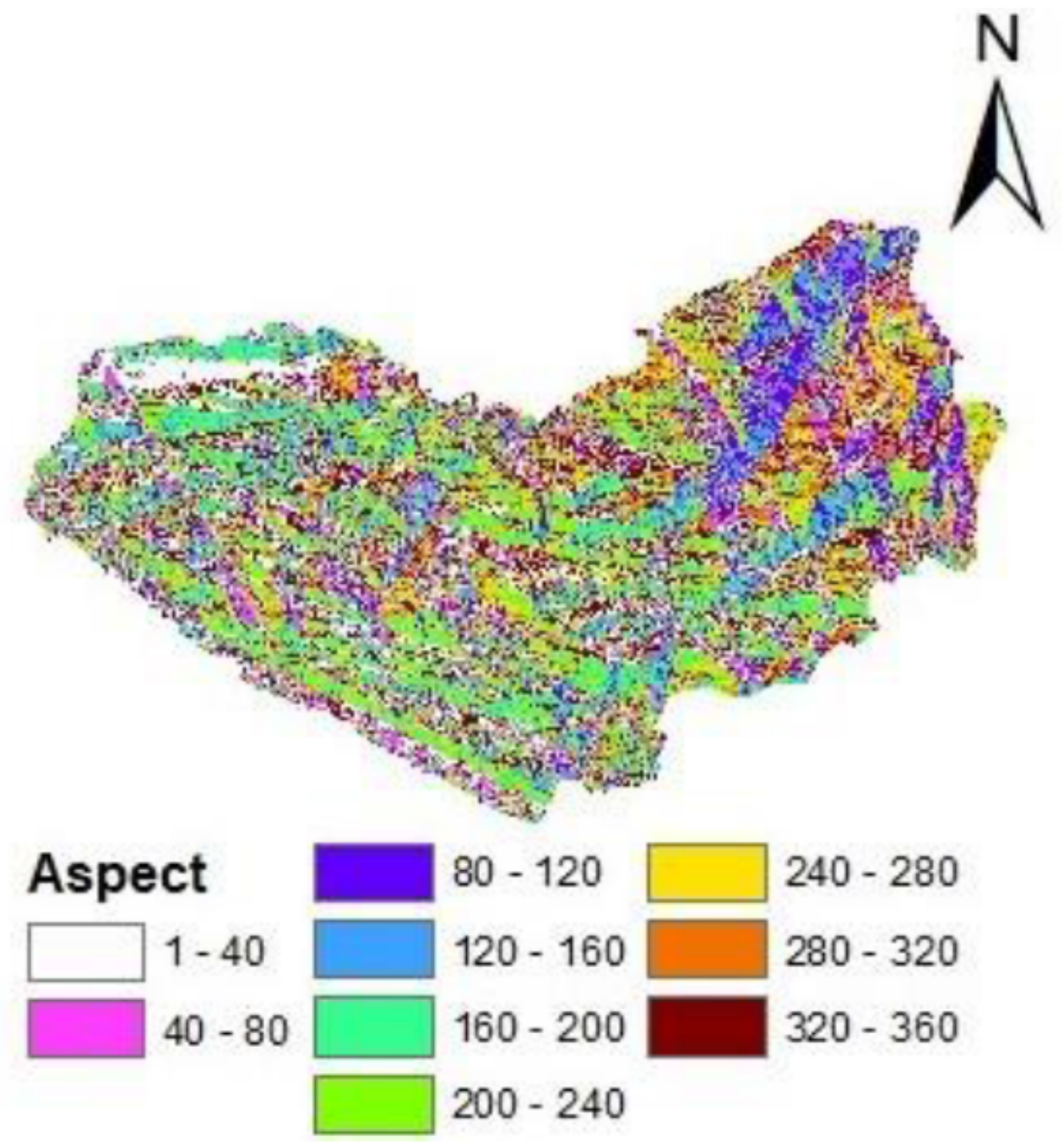

\section{Figure 5}

Slope aspect map for the study area. Note: The designations employed and the presentation of the material on this map do not imply the expression of any opinion whatsoever on the part of Research Square concerning the legal status of any country, territory, city or area or of its authorities, or concerning the delimitation of its frontiers or boundaries. This map has been provided by the authors. 


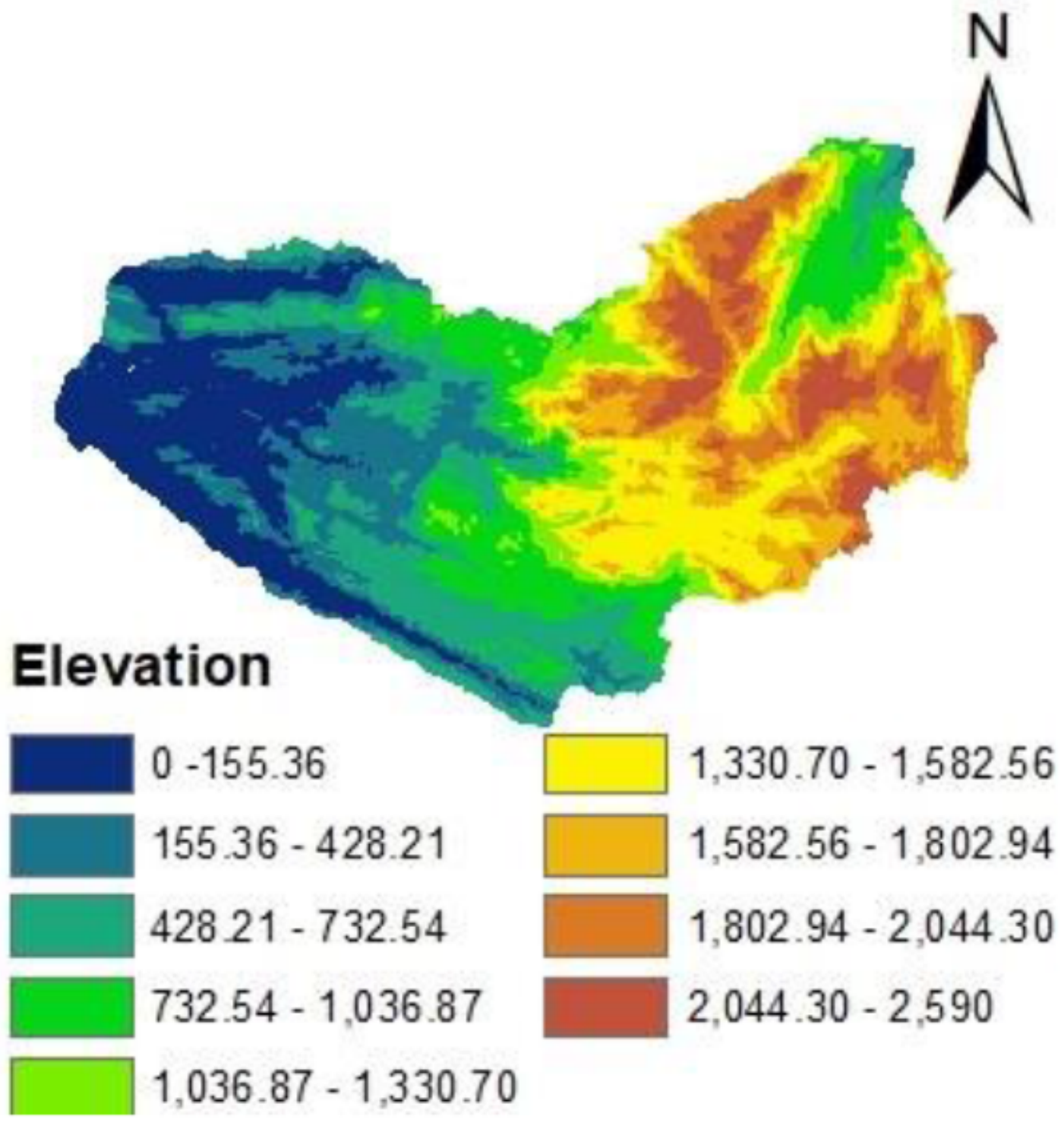

Figure 6

Elevation map of the study area. Note: The designations employed and the presentation of the material on this map do not imply the expression of any opinion whatsoever on the part of Research Square concerning the legal status of any country, territory, city or area or of its authorities, or concerning the delimitation of its frontiers or boundaries. This map has been provided by the authors. 


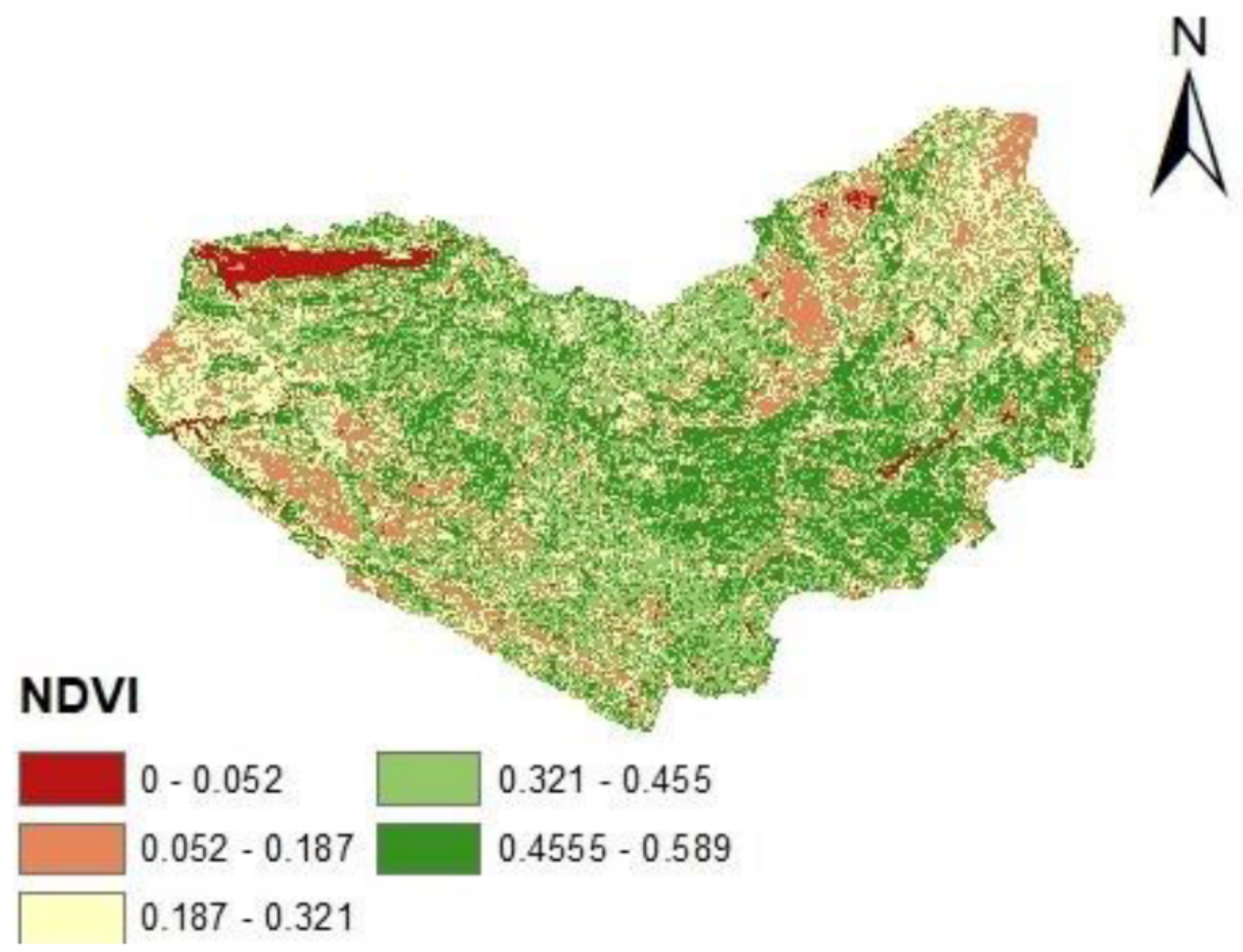

Figure 7

shows the NDVI value of the study area. Note: The designations employed and the presentation of the material on this map do not imply the expression of any opinion whatsoever on the part of Research Square concerning the legal status of any country, territory, city or area or of its authorities, or concerning the delimitation of its frontiers or boundaries. This map has been provided by the authors. 


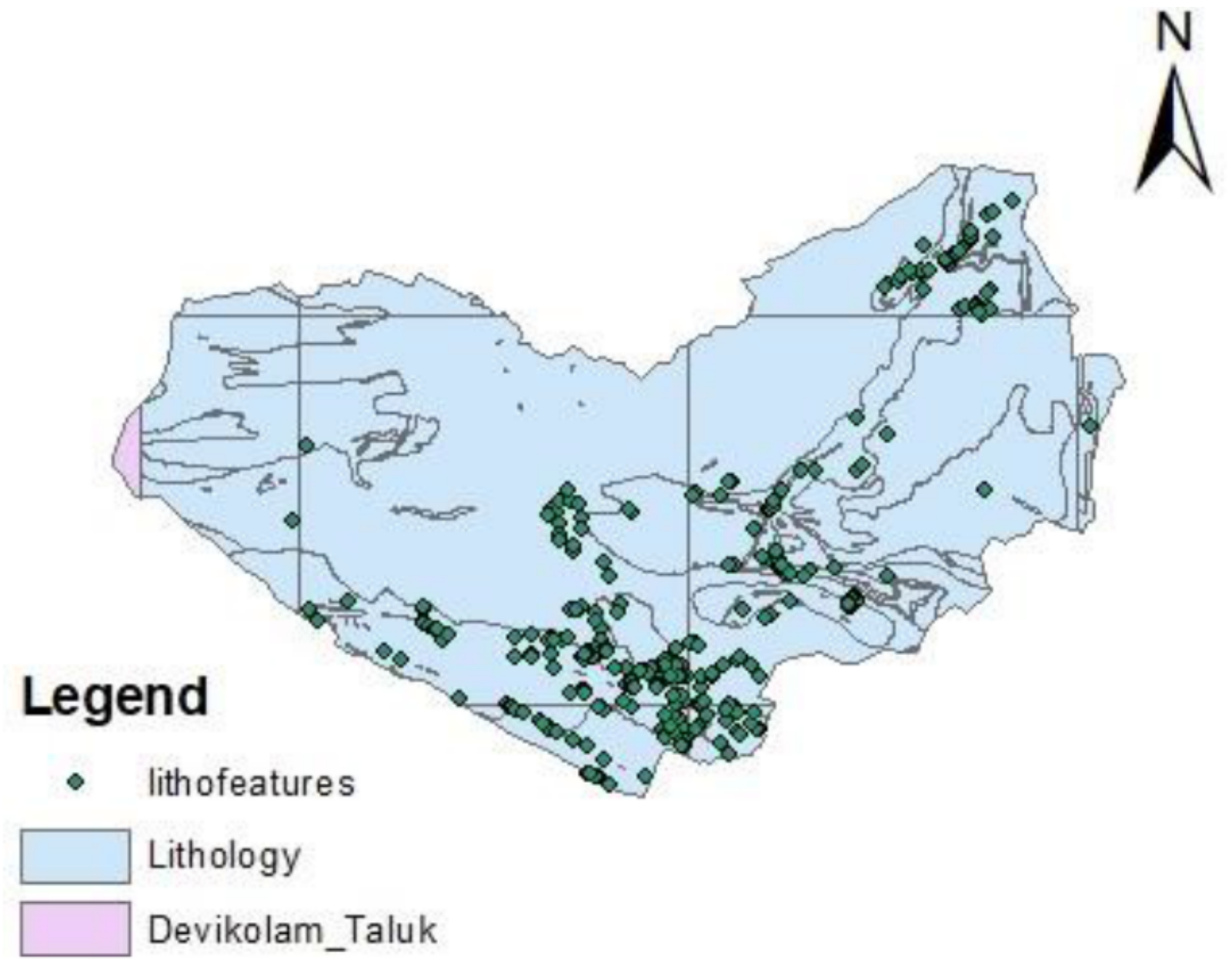

Figure 8

Lithological features of devikulam taluk. Note: The designations employed and the presentation of the material on this map do not imply the expression of any opinion whatsoever on the part of Research Square concerning the legal status of any country, territory, city or area or of its authorities, or concerning the delimitation of its frontiers or boundaries. This map has been provided by the authors. 


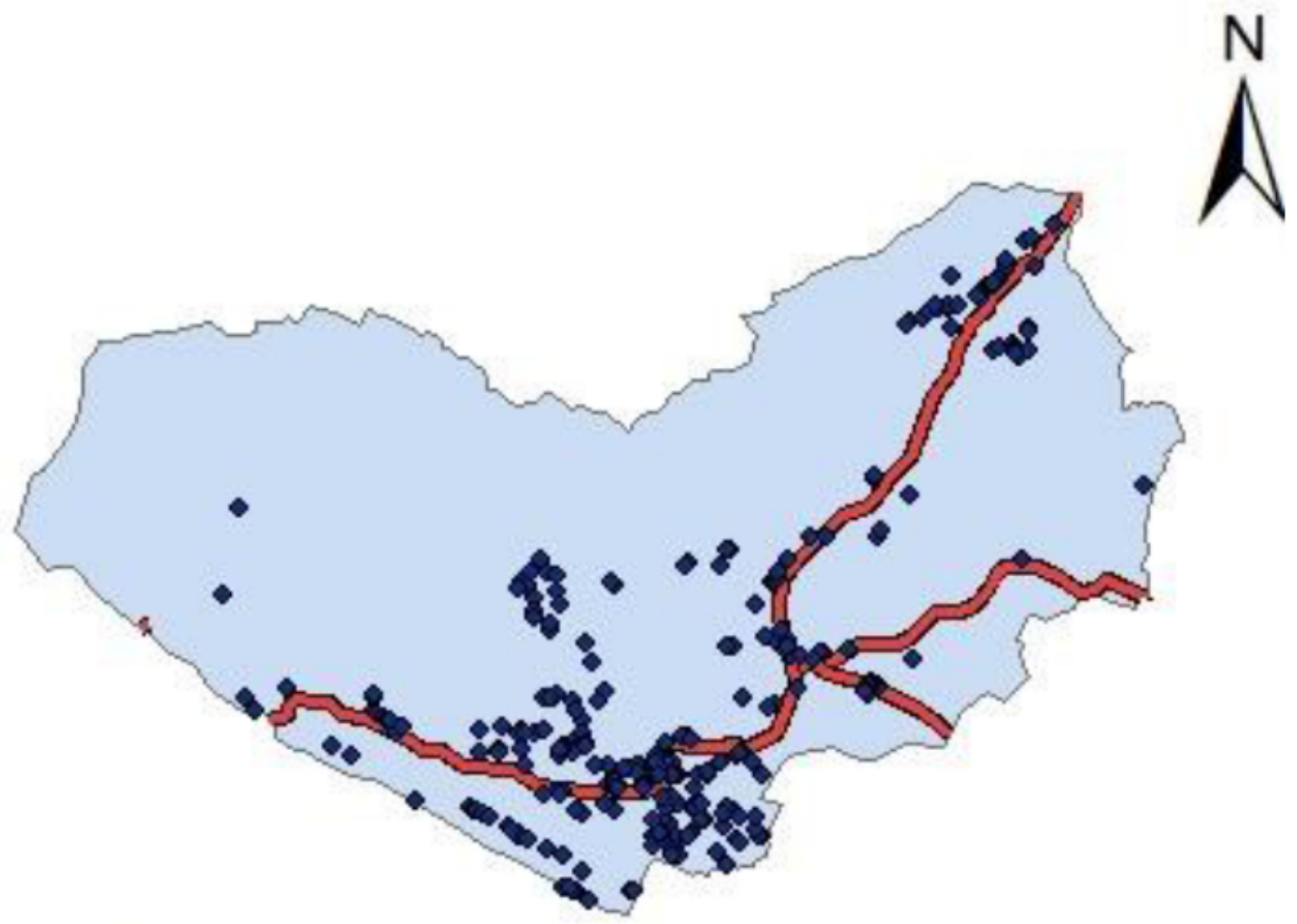

\section{Legend}

\section{- roadfeatures $=$ Clipped_Road $\square$ Devikolam_Taluk}

\section{Figure 9}

Red colour road represents the major route in Devikulam taluk. Note: The designations employed and the presentation of the material on this map do not imply the expression of any opinion whatsoever on the part of Research Square concerning the legal status of any country, territory, city or area or of its authorities, or concerning the delimitation of its frontiers or boundaries. This map has been provided by the authors. 

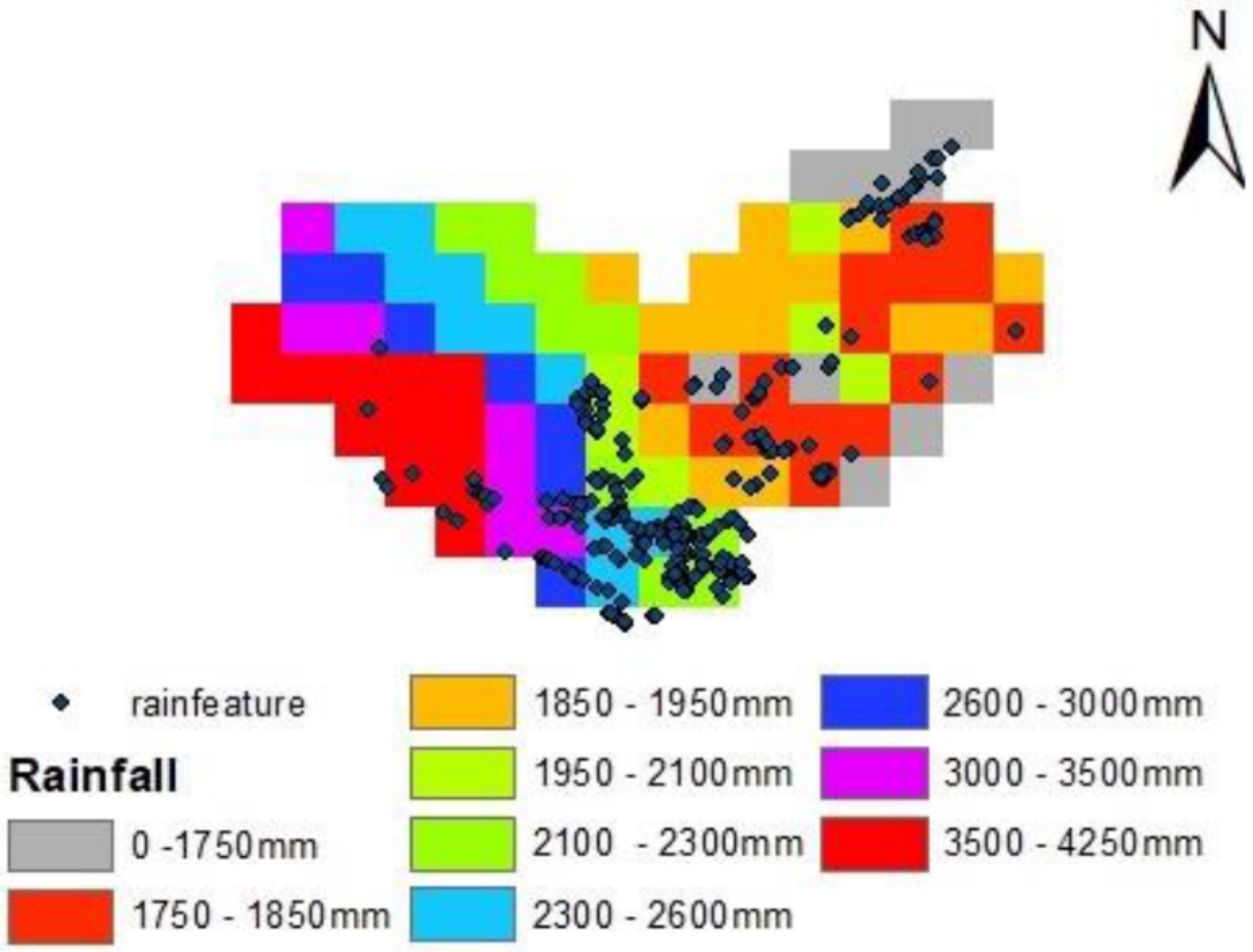

Figure 10

Rainfall ranges with its landslide potential points in Devikulam taluk. Note: The designations employed and the presentation of the material on this map do not imply the expression of any opinion whatsoever on the part of Research Square concerning the legal status of any country, territory, city or area or of its authorities, or concerning the delimitation of its frontiers or boundaries. This map has been provided by the authors. 


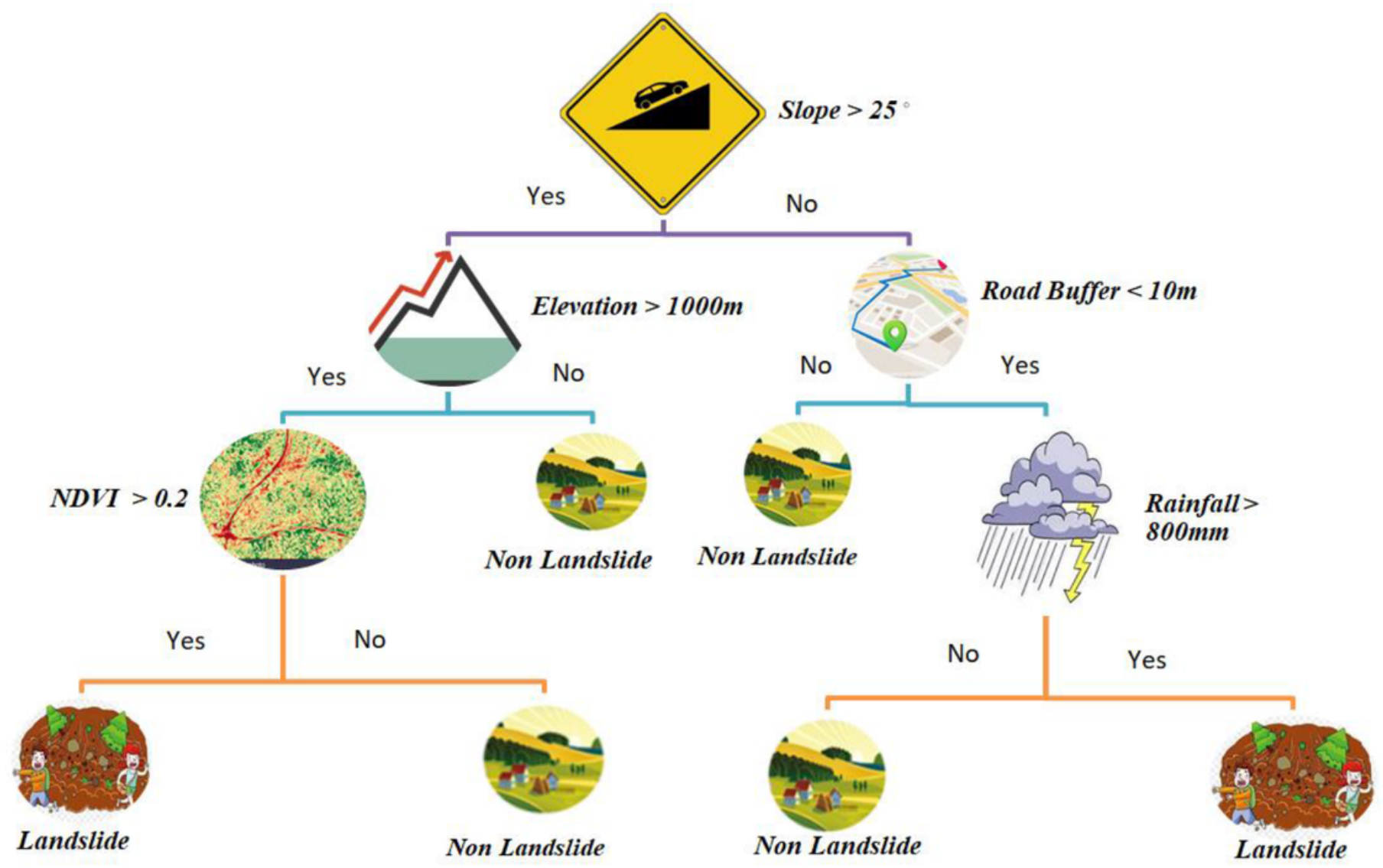

Figure 11

Decision tree model for landslide classification. 


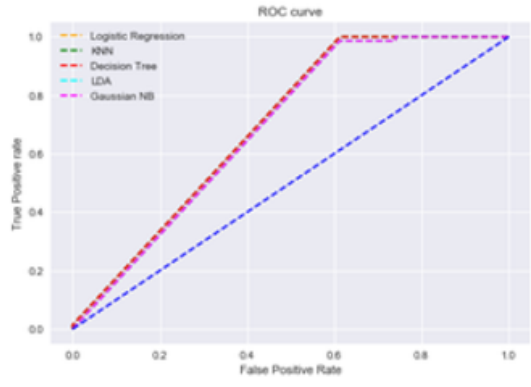

F1 - Slope

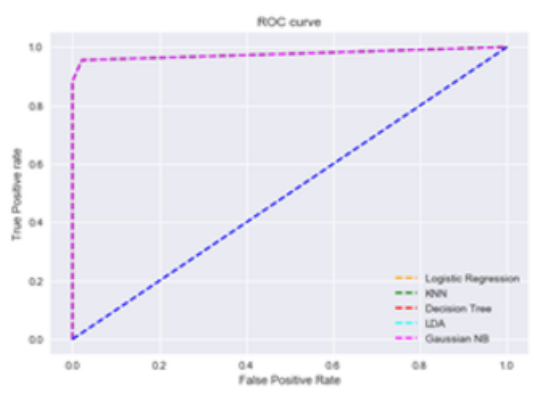

F4 - NDVI

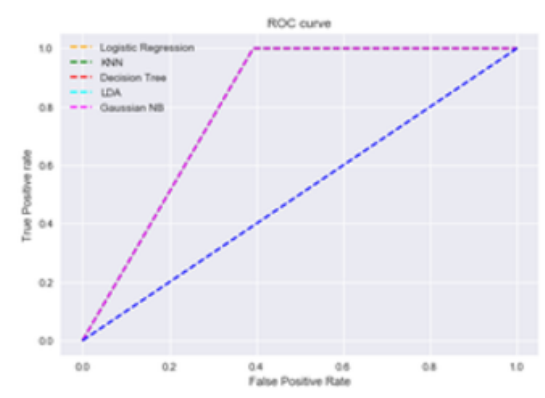

F7 - Rainfall

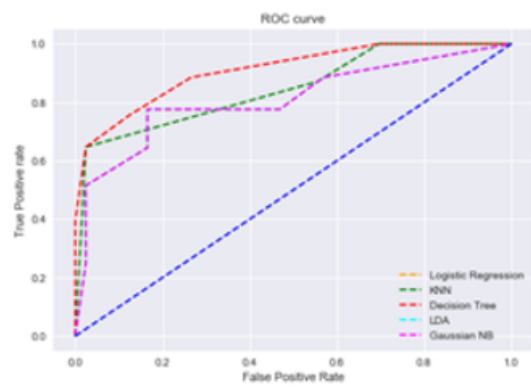

F2 - Aspect

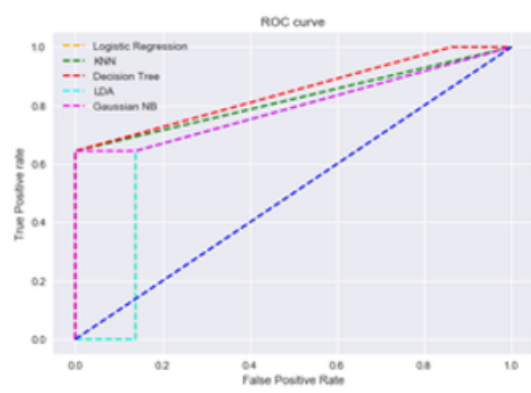

F5 - Road

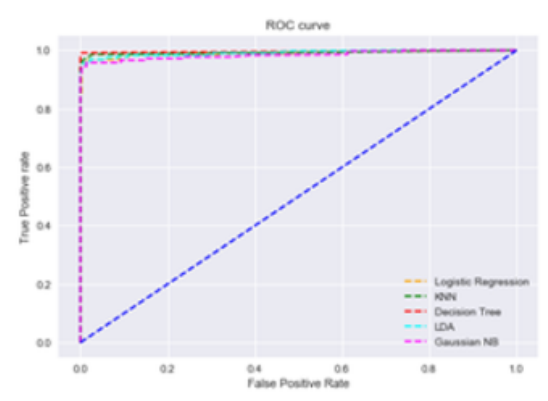

$\mathrm{F} 1, \mathrm{~F} 2, \mathrm{~F} 3, \mathrm{~F} 4$

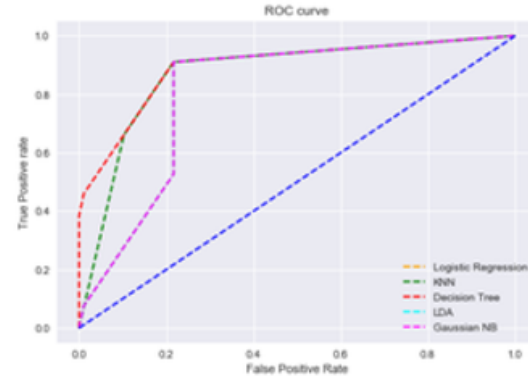

F3 - Elevation

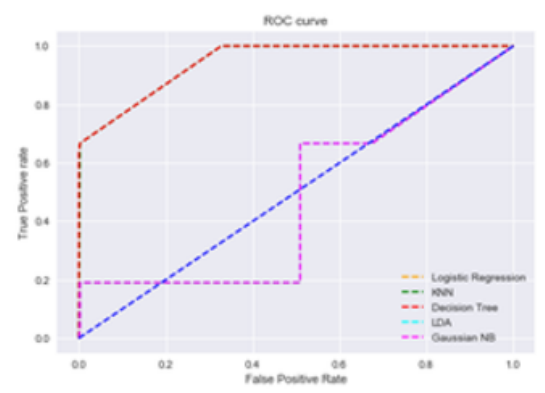

F6 - Lithology

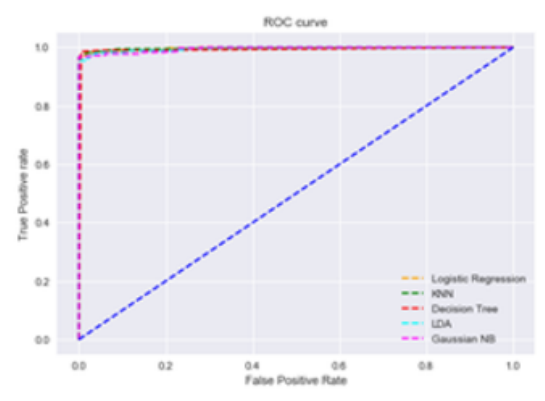

F1 to F7

Figure 12

ROC curve for machine learning Classifiers with individual parameters 